\title{
TSCHECHEN UND DEUTSCHE, 1939-1946. By Johann Wolfgang Brïgel. \\ Munich: Nymphenburger Verlagshandlung, 1974. 326 pp. DM 65.
}

This is the second volume of J. W. Brügel's study of German-Czech relations. The first volume, covering the years from the establishment of the First Czechoslovak Republic in 1918 to its collapse after the Munich conference in 1938, was published in 1967. Cambridge University Press published an English translation of that volume in 1973, under the title Czechoslovakia Before Munich: The German Minority Problem and British Appeasement Policy. Although the translation was somewhat abridged, it contained much new archival material, notably the records of the British Foreign Office, which had in the meantime been opened to historians. Both the German edition and the English translation, although they dealt with a highly emotional subject, won high critical praise for meticulous scholarship and scrupulous objectivity.

The present volume, which covers the years from the German occupation of Bohemia and Moravia in 1939 to the expulsion of the Sudeten German minority from reconstituted Czechoslovakia in 1946, continues the high standards of the first volume. It is based on rich archival material, as well as sources published in German, Czech, and English. The author is a native of Czechoslovakia, of German nationality, and was active in the German Social Democratic Party of Czechoslovakia before the war. Unlike other Sudeten German activist parties, which were stampeded by Nazi propaganda into joining Konrad Henlein's pro-Nazi Sudeten German Party in 1938, the German Social Democratic Party remained loyal to the Czechoslovak democracy until the bitter end. For this it suffered Nazi revenge in 1938, but did not win Czech recognition in 1945. When Czechoslovakia was restored, former Sudeten German Social Democrats were expelled from the country, along with former Sudeten German Nazis.

The tragic fate of the German Social Democratic Party embittered many of its surviving members. The last chairman of the party, Wenzel Jaksch, cooperated with President Benes in wartime London, to which they both had fled. After the war, however, when the Czechoslovak government acted on the principle of collective guilt and expelled most of the Sudeten German minority, Jaksch went to West Germany, where he made a career (he was elected to the West German parliament) of denouncing Czechoslovakia and everything it had ever stood for. On the other hand, Brügel, who had likewise fled to London, where he continues to reside, has resisted the temptation to settle accounts with the Czechs. He apportions the responsibility for the tragedy of Czech-German relations even-handedly: he blames Hitler's government unsparingly for destroying Czechoslovakia and oppressing the Czechs harshly during the war, the Czechoslovak government for indiscriminately. expelling the whole Sudeten German minority after the war, and the Allied governments for sanctioning the expulsion at the Potsdam conference.

If there is any weakness in this study, it is in its method. Instead of presenting a continuous narrative, Brügel fragments the subject into innumerable, meticulously sketched episodes. He thus tends to obscure the evolution and continuity of German, Czechoslovak, and Allied policy. But this is not a fatal flaw. Hopefully, Cambridge University Press will find it possible to publish an English translation of the present volume also. 